\title{
Water Resources of Natchitoches Parish, Louisiana
}

\section{Introduction}

In 2005, about 33.8 million gallons per day (Mgal/d) was withdrawn from water sources in Natchitoches Parish, Louisiana $^{1}$ (fig. 1). Surface water sources accounted for about 86 percent $(29.2 \mathrm{Mgal} / \mathrm{d})$ of all withdrawals whereas groundwater sources accounted for about 14 percent (4.62 Mgal/d) (table 1). Withdrawals for industrial use accounted for about 42 percent $(14.1 \mathrm{Mgal} / \mathrm{d})$ of the total

${ }^{1}$ Tabulation of numbers in text and tables may result in different totals because of rounding; nonrounded numbers are used for calculation of totals. water withdrawn (table 2). Other categories of use included public supply, rural domestic, livestock, rice irrigation, general irrigation, and aquaculture. The city of Natchitoches used almost $5.6 \mathrm{Mgal} / \mathrm{d}$ (about $5.2 \mathrm{Mgal} / \mathrm{d}$ of surface water and $0.4 \mathrm{Mgal} / \mathrm{d}$ of ground water) for public supply. Water-use data collected at 5-year intervals from 1960 to 2005 indicated that total water withdrawals increased from about $3.5 \mathrm{Mgal} / \mathrm{d}$ in 1960 to a peak of almost $35 \mathrm{Mgal} / \mathrm{d}$ in 2000 (fig. 2).

This fact sheet summarizes basic information on the water resources of Natchitoches Parish. Information on groundwater and surface-water availability, quality, development, use, and trends is based on previously published reports listed in the Selected References section.

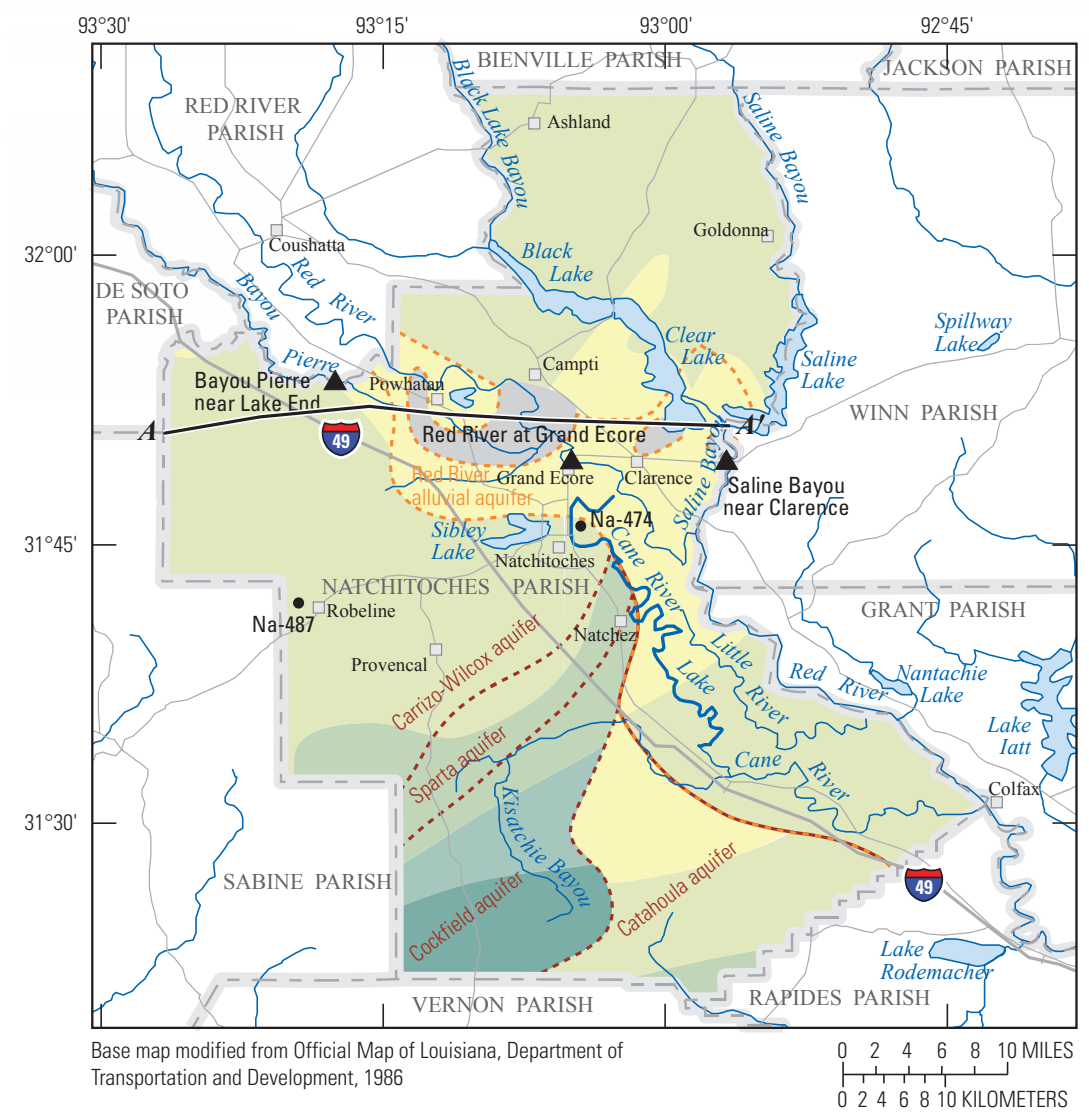

\section{EXPLANATION}

Area where no major aquifer contains fresh groundwater

Approximate altitude of base of fresh groundwater, in feet below National Geodetic Vertical Datum of 1929 (NGVD 29) (modified from Smoot, 1988)—Deepest freshwater contained within Carrizo-Wilcox aquifer, except where noted

Above NGVD 29

0 to 499

500 to 999

1,000 to 1,499

1,500 to 2,000

- - - - - Boundary of area showing deepest

freshwater contained within overlying Alluvial aquifer

- . - . - Boundary of area showing deepest freshwater contained within underlying Sparta, Cockfield, and Catahoula aquifers

$A-A^{\prime}$ Trace of hydrogeologic section (see fig. 3)

- Well for which hydrograph is Na-487 shown and identifier (see fig. 4) U.S. Geological Survey surface-water Saline Bayou site and station name (see table 4) near Clarence

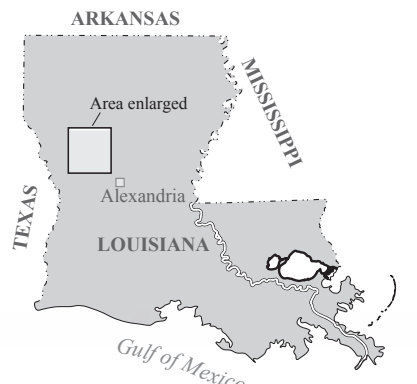

Figure 1. Location of study area, Natchitoches Parish, Louisiana. (Note, the Black Lake reservoir comprises Black Lake and Clear Lake.) 
Table 1. Water withdrawals, in million gallons per day, by source in Natchitoches Parish, Louisiana, 2005 (modified from Sargent, 2007).

\begin{tabular}{lcc}
\hline \multicolumn{1}{c}{$\begin{array}{c}\text { Aquifer or } \\
\text { surface-water body }\end{array}$} & Groundwater & Surface water \\
\hline Red River alluvial aquifer & 2.65 & - \\
Upland terrace aquifer & 0.12 & - \\
Catahoula aquifer & 0.03 & - \\
Cockfield aquifer & 0.04 & - \\
Sparta aquifer & 0.50 & - \\
Carrizo-Wilcox aquifer & 1.23 & 3.17 \\
Other aquifers & 0.05 & 1.24 \\
Bayou Pierre & - & 0.45 \\
Black Lake reservoir ${ }^{1}$ & - & 2.83 \\
Cane River & - & 12.88 \\
Little River & - & 5.18 \\
Red River & - & 3.44 \\
Sibley Lake & - & 29.19 \\
Miscellaneous streams & - & \\
Total & 4.62 & \\
'Black Lake reservoir consists of two interconnected lakes, Black Lake and \\
Clear Lake.
\end{tabular}

Table 2. Water withdrawals, in million gallons per day, by category in Natchitoches Parish, Louisiana, 2005 (modified from Sargent, 2007).

\begin{tabular}{lcrr}
\hline \multicolumn{1}{c}{ Category } & Groundwater & $\begin{array}{c}\text { Surface } \\
\text { Water }\end{array}$ & Total \\
\hline Public supply & 1.08 & 5.20 & 6.29 \\
Industrial & 0.00 & 14.10 & 14.10 \\
Rural domestic & 0.51 & 0.00 & 0.51 \\
Livestock & 0.28 & 0.00 & 0.28 \\
Rice irrigation & 0.88 & 5.01 & 5.89 \\
General irrigation & 0.33 & 1.31 & 1.64 \\
Aquaculture & 1.53 & 3.57 & 5.11 \\
\cline { 2 - 4 } Total & 4.62 & 29.19 & 33.81 \\
\hline
\end{tabular}

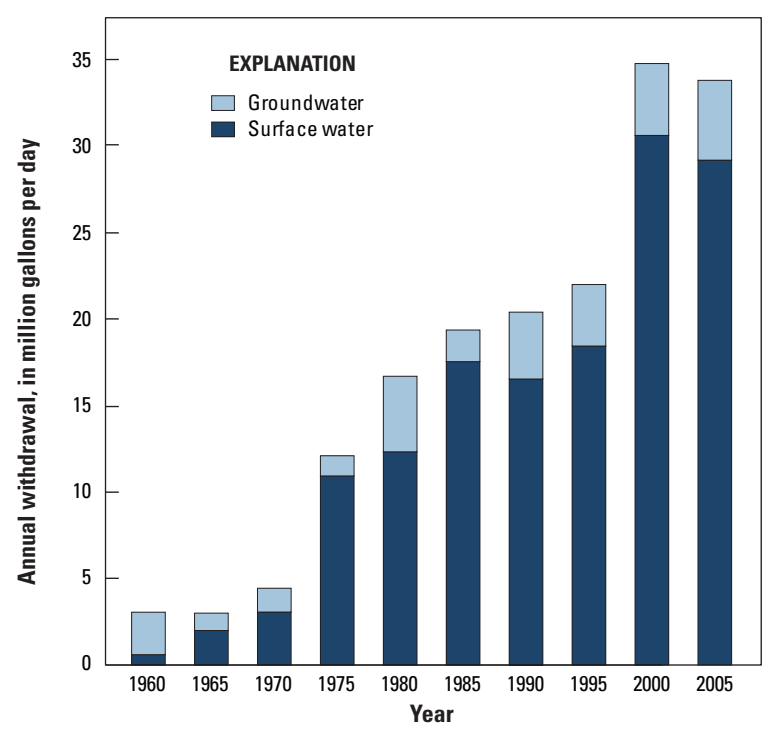

Figure 2. Water withdrawals in Natchitotches Parish, Louisiana, 1960-2005.

\section{Groundwater Resources}

The primary groundwater resources of Natchitoches Parish, from near surface to deepest, include the Red River alluvial, upland terrace, Sparta, and Carrizo-Wilcox aquifers (fig. 3). The Catahoula and Cockfield aquifers are also sources of freshwater in some parts of the parish (table 1) but are not considered major resources because of their limited extents within the parish; consequently, they are not discussed in this report. Fresh groundwater (water with a chloride concentration of less than 250 milligrams per liter [mg/L]) is available throughout the parish at depths ranging from near land surface to about 2,000 feet (ft) below the National Geodetic Vertical Datum of 1929 (NGVD 29) in the southwestern part of the parish (fig. 1).

Recharge to aquifers is from rainfall, leakage from adjacent aquifers, and rivers during periods of high flow. Discharge from the aquifers is by natural flow into rivers during periods of low flow, leakage into underlying aquifers, and withdrawal from wells.

State well-registration records listed 876 active water wells in Natchitoches Parish in 2010, including 671 domestic, 115 irrigation, 75 public-supply, and 15 industrial use wells. In 2005, groundwater withdrawals for various uses included public supply, rural domestic, livestock, rice irrigation, general irrigation, and aquaculture (table 2).

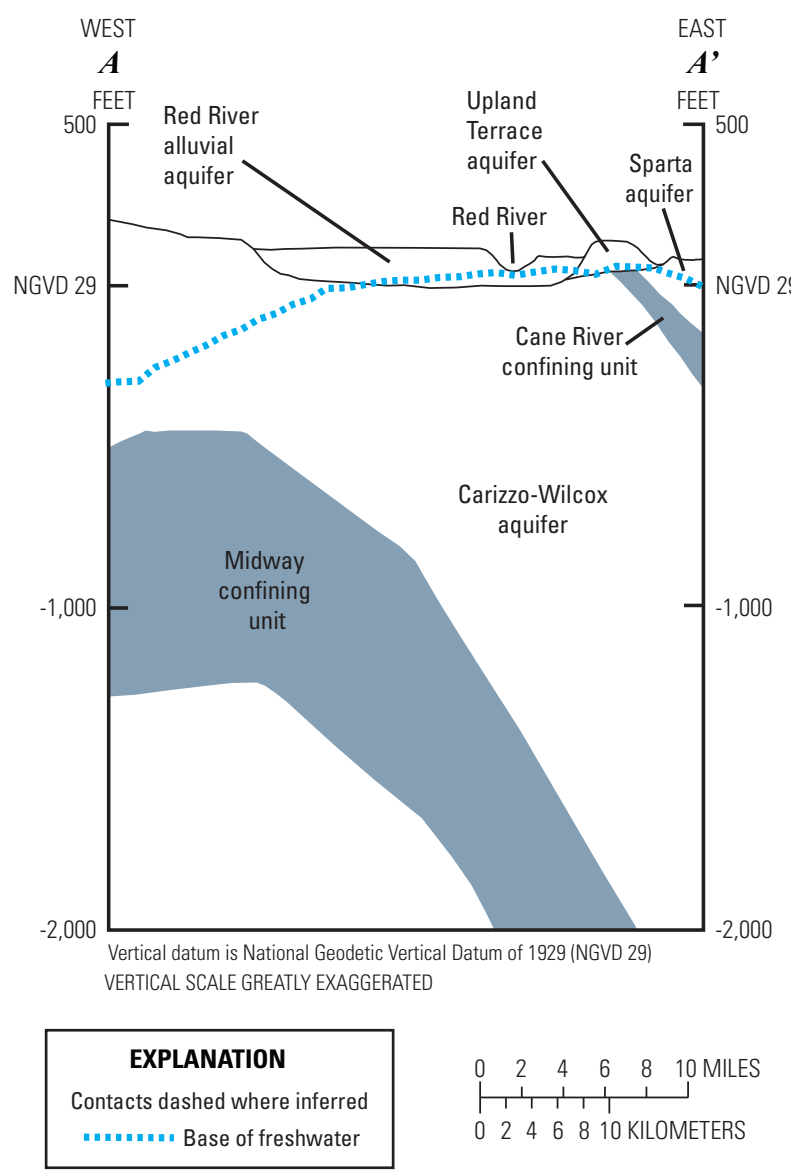

Figure 3. Generalized west-to-east hydrogeologic section through Natchitoches Parish, Louisiana (modified from Smoot, 1989). Trace of section shown on figure 1. 


\section{Red River Alluvial Aquifer}

The Red River alluvial aquifer is the most heavily pumped aquifer in Natchitoches Parish. The aquifer consists of gray and brown poorly-sorted sand and gravel and covers about a third of the parish. The Red River alluvial aquifer trends toward the southeast, through the central portion of the parish. It underlies the present course of the Red River and has a maximum width of about 16 miles (mi). A few miles south of the city of Natchitoches, the Red River is near the eastern boundary of the aquifer. In Natchitoches Parish, the maximum thickness of the Red River alluvial aquifer is about $60 \mathrm{ft}$, with an average thickness of about $45 \mathrm{ft}$.

Saltwater is present in the Red River alluvial aquifer in a few localized areas in Natchitoches Parish where highly mineralized water from underlying aquifers is discharged into the alluvial aquifer. Where saltwater is present, however, it is stratified with freshwater at shallower depths overlying saltwater at the base of the aquifer (fig. 3).

Recharge to the aquifer is from rainfall, leakage from adjacent aquifers, and the waters of Cane River Lake. Water levels in the alluvial aquifer fluctuate primarily in response to the stage of the Red River and precipitation. The hydrograph for well Na-474, which is located near the City of Natchitoches, shows seasonal water-level fluctuations of about 6 to 8 feet ( $\mathrm{ft}$ ) during the period 1989-2010 (fig. 4). Flow in the aquifer is generally towards the Red River with a southerly (down valley) component of flow.

State well-registration records listed 146 active wells screened in the Red River alluvial aquifer in Natchitoches Parish in 2010, including 70 domestic, 67 irrigation, 5 industrial, and 4 public-supply wells. Depths of these wells ranged from 17 to $150 \mathrm{ft}$ below land surface with a median well depth of $85 \mathrm{ft}$. Yields from wells screened in the Red River alluvial aquifer in Natchitoches Parish range from 1 to 1,500 gallons per minute (gal/min) with most yields (73 percent) less than $80 \mathrm{gal} / \mathrm{min}$. In 2005, groundwater withdrawals from the Red River alluvial aquifer in Natchitoches Parish totaled about $2.65 \mathrm{Mgal} / \mathrm{d}$, primarily for rural domestic use and irrigation.

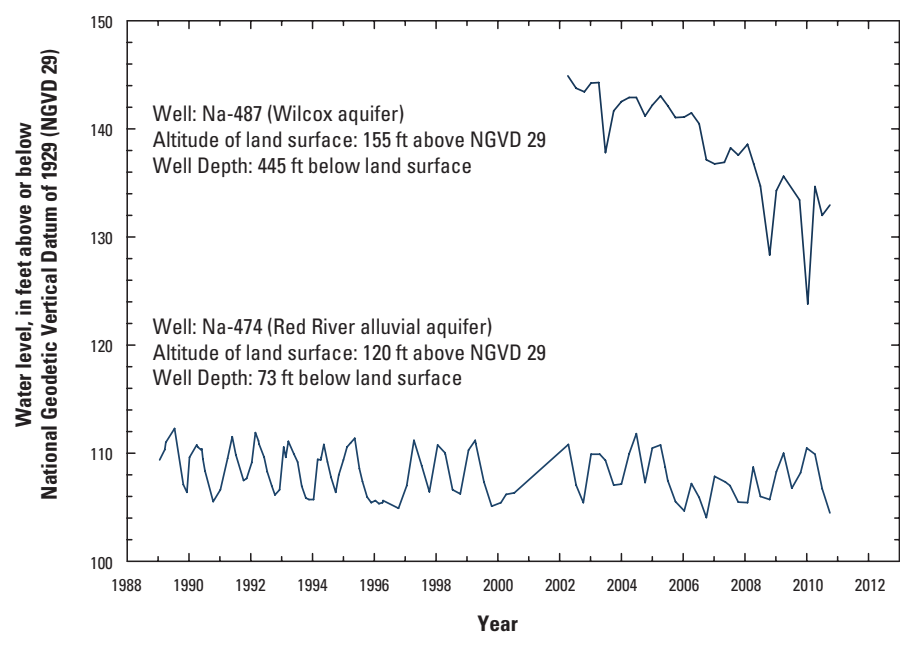

Figure 4. Water levels in well Na-474 screened in the Red River alluvial aquifer and well Na-487 screened in the Wilcox aquifer in Natchitoches Parish, Louisiana (see fig. 1 for well locations) (U.S. Geological Survey, 2012a). Land surface is measured in feet ( $\mathrm{ft}$ ) above the National Geodetic Vertical Datum of 1929 (NGVD 29).
A statistical summary of selected water-quality characteristics for freshwater samples collected from 101 wells screened in the Red River alluvial aquifer in Natchitoches Parish is listed in table 3. Based on median values for hardness, ${ }^{2}$ water from the Red River alluvial aquifer is generally very hard. Water in less than one-third (31 percent) of the sampled wells was below the U.S. Environmental Protection Agency's (EPA) Secondary Maximum Contaminant Level (SMCL) 3 of $500 \mathrm{mg} / \mathrm{L}$ for dissolved solids concentration. Water from the aquifer generally does not exceed the SMCLs for $\mathrm{pH}$, color, and chloride concentrations but generally exceeds the SMCLs of 300 micrograms per liter $(\mu \mathrm{g} / \mathrm{L})$ for iron concentrations and $50 \mu \mathrm{g} / \mathrm{L}$ for manganese concentrations.

\section{Upland Terrace Aquifer}

The upland terrace aquifer, consisting of clay, sand, and gravel, covers only about 10 percent of the parish. The aquifer is principally located in the northern part of the parish between the Red River and the chain formed by Black Lake and Clear Lake (fig. 1). Sands are generally yellow or gray at depth, and red in weathered outcrops. The thickness of these deposits probably does not exceed $100 \mathrm{ft}$, with an average thickness of about $50 \mathrm{ft}$. Water levels in the aquifer fluctuate rapidly and through a considerable range in response to rainfall.

State well-registration records listed 128 active wells screened in the upland terrace aquifer in Natchitoches Parish in 2010, including 116 domestic, 8 public supply, 2 irrigation, and 2 industrial wells. Depths of these wells ranged from 12 to $125 \mathrm{ft}$ below land surface with a median well depth of $56 \mathrm{ft}$. Yields from wells screened in the upland terrace aquifer in Natchitoches Parish range from 5 to $255 \mathrm{gal} / \mathrm{min}$. In 2005, groundwater withdrawals from the upland terrace aquifer in Natchitoches Parish totaled about $0.12 \mathrm{Mgal} / \mathrm{d}$, primarily for rural domestic use.

Because few water-quality data are available for the upland terrace aquifer in Natchitoches Parish, water quality is not discussed in this report.

\section{Sparta Aquifer}

The Sparta aquifer generally underlies the southern half of Natchitoches Parish and is present along the northeastern parish line. The Sparta aquifer outcrops in a narrow band in the northeast and central portion of the parish and consists of light gray sand and clay. Grain size varies from fine sand to coarse sand. The thickness of the aquifer in Natchitoches Parish ranges from about $250 \mathrm{ft}$ to more than $600 \mathrm{ft}$. Individual sand beds in the lower part of the Sparta aquifer are as much as $250 \mathrm{ft}$ thick. Groundwater flow is generally downdip to the south and east. Freshwater is present in the Sparta aquifer in northeastern Natchitoches Parish and in a 5- to 10mi-wide band extending southwest from the southern end of Saline

${ }^{2}$ Hardness ranges, expressed as milligrams per liter of calcium carbonate, are as follows: 0-60, soft; 61-120, moderately hard; 121-180, hard; greater than 180, very hard (Hem, 1985).

${ }^{3}$ The SMCLs are nonenforceable Federal guidelines regarding cosmetic effects (such as tooth or skin discoloration) or aesthetic effects (such as taste, odor, or color) of drinking water. At high concentrations or values, health implications as well aesthetic degradation might exist. SMCLs were established as guidelines for the states by the U.S. Environmental Protection Agency (1992). 
Table 3. Summary of selected water-quality characteristics of freshwater for the Red River alluvial, Sparta, and Carrizo-Wilcox aquifers in Natchitoches Parish, Louisiana (U.S. Geological Survey, 2012b).

[Values are in milligrams per liter, except as noted. ${ }^{\circ} \mathrm{C}$, degrees Celsius; $\mathrm{PCU}$, platinum cobalt units; $\mu \mathrm{S} / \mathrm{cm}$, microsiemens per centimeter at $25^{\circ} \mathrm{C} ; \mathrm{SU}$, standard units; $\mathrm{CaCO}_{3}$, calcium carbonate; $\mu \mathrm{g} / \mathrm{L}$, micrograms per liter; <, less than; NA, not applicable; —, insufficient data; SMCL, Secondary Maximum Contaminant Level established by the U.S. Environmental Protection Agency (2011)]

\begin{tabular}{|c|c|c|c|c|c|c|c|c|c|}
\hline & $\begin{array}{l}\text { Temper- } \\
\text { ature } \\
\left({ }^{\circ} \mathrm{C}\right)\end{array}$ & $\begin{array}{l}\text { Color } \\
\text { (PCU) }\end{array}$ & $\begin{array}{c}\text { Specific } \\
\text { conductance, } \\
\text { field }(\mu \mathrm{S} / \mathrm{cm} \\
\left.\text { at } 25^{\circ} \mathrm{C}\right)\end{array}$ & $\begin{array}{c}\mathrm{pH}, \\
\text { field (SU) }\end{array}$ & $\begin{array}{l}\text { Hardness } \\
\text { (as } \mathrm{CaCO}_{3} \text { ) }\end{array}$ & $\begin{array}{l}\text { Chloride, } \\
\text { filtered } \\
\text { (as CI) }\end{array}$ & $\begin{array}{l}\text { Iron, } \\
\text { filtered } \\
\text { ( } \mu \mathrm{g} / \mathrm{L} \text { as } \\
\text { Fe) }\end{array}$ & $\begin{array}{l}\text { Manganese, } \\
\text { filtered } \\
\text { ( } \mu \mathrm{g} / \mathrm{L} \text { as } \mathrm{Mn} \text { ) }\end{array}$ & $\begin{array}{l}\text { Dissolved } \\
\text { solids, } \\
\text { filtered }\end{array}$ \\
\hline \multicolumn{10}{|c|}{ Red River alluvial aquifer, 1940-2000 } \\
\hline Median & 20.5 & $<5$ & 1,040 & 7.1 & 440 & 32 & 4,500 & 430 & 672 \\
\hline 10th percentile & 19.5 & 0 & 660 & 6.8 & 260 & 7.4 & 1,300 & 150 & 384 \\
\hline 90th percentile & 21.3 & 10 & 1,590 & 7.4 & 600 & 150 & 8,800 & 1,300 & 936 \\
\hline Number of samples & 37 & 24 & 63 & 65 & 95 & 99 & 65 & 67 & 29 \\
\hline $\begin{array}{l}\text { Percentage of samples } \\
\text { that do not exceed } \\
\text { SMCLs }\end{array}$ & NA & 96 & NA & 100 & NA & 100 & 5 & 4 & 31 \\
\hline \multicolumn{10}{|c|}{ Sparta aquifer, 1940-74 } \\
\hline Median & 22.0 & 5 & 522 & 7.6 & 12 & 20 & 130 & 40 & 333 \\
\hline 10 th percentile & 20.6 & 0 & 59 & 5.7 & 5 & 5.2 & 80 & - & 60 \\
\hline 90th percentile & 24.5 & 25 & 1,140 & 8.1 & 75 & 140 & 1,400 & - & 632 \\
\hline Number of samples & 5 & 11 & 20 & 20 & 30 & 30 & 6 & 2 & 18 \\
\hline $\begin{array}{l}\text { Percentage of samples } \\
\text { that do not exceed } \\
\text { SMCLs }\end{array}$ & NA & 64 & NA & 80 & NA & 100 & 67 & 50 & 78 \\
\hline \multicolumn{10}{|c|}{ Carrizo-Wilcox aquifer, 1940-2004 } \\
\hline Median & 20.5 & 18 & 1,040 & 8.0 & 22 & 39 & 140 & 35 & 566 \\
\hline 10th percentile & 19.5 & 5 & 255 & 6.9 & 4 & 9.2 & 30 & 4 & 198 \\
\hline 90th percentile & 21.5 & 100 & 1,740 & 8.9 & 190 & 140 & 1,900 & 1,200 & 1,250 \\
\hline Number of samples & 11 & 26 & 31 & 32 & 52 & 53 & 22 & 10 & 32 \\
\hline $\begin{array}{l}\text { Percentage of samples } \\
\text { that do not exceed } \\
\text { SMCLs }\end{array}$ & NA & 46 & NA & 75 & NA & 100 & 64 & 60 & 41 \\
\hline \multicolumn{10}{|c|}{ SMCLs } \\
\hline & NA & 15 & NA & $6.5-8.5$ & NA & 250 & 300 & 50 & 500 \\
\hline
\end{tabular}

Lake into Sabine Parish. Saltwater is present in the Sparta aquifer in most southern and southeastern areas of Natchitoches Parish.

State well-registration records listed 54 active wells screened in the Sparta aquifer in Natchitoches Parish in 2010, including 43 domestic, 10 public supply, and 1 irrigation well. Depths of these wells ranged from 15 to $725 \mathrm{ft}$ below land surface with a median well depth of $145 \mathrm{ft}$. Yields from wells screened in the aquifer in the parish range from 4 to $365 \mathrm{gal} /$ min. In 2005, groundwater withdrawals from the Sparta aquifer in Natchitoches Parish totaled about $0.50 \mathrm{Mgal} / \mathrm{d}$, primarily for public supply.

A statistical summary of selected water-quality characteristics for water samples collected from 30 wells screened in freshwater areas of the Sparta aquifer in Natchitoches Parish is listed in table 3. Based on median values, water from the Sparta aquifer is generally soft and generally does not exceed SMCLs for $\mathrm{pH}$, color, and iron and dissolved solids concentrations. Water in some areas, however, may exceed the SMCLs for iron or manganese.

\section{Carrizo-Wilcox Aquifer}

The Carrizo-Wilcox aquifer underlies all of Natchitoches Parish and outcrops north of Black Creek in the northwest part of the parish and west of the city of Natchitoches in the western part of the parish. The Carrizo Sand is a discontinuous, massive sand that overlies the eroded surface of the Wilcox aquifer. Regionally, the Carrizo Sand and the Wilcox aquifer are hydraulically connected, and the units are combined into one aquifer. The Carrizo Sand consists of light colored, fine to medium grained material with an average thickness of about $75 \mathrm{ft}$ in the parish. Sands in the Wilcox aquifer are interbedded with dark clay and generally are fine grained, homogeneous, and typically dark, almost black in many places, because of the lignite and glauconite in the formation.

The total thickness of the Carrizo-Wilcox aquifer in Natchitoches Parish ranges from about 300 to 3,700 ft, but the thicknesses of the individual sand beds within the aquifer generally range from about $1 \mathrm{ft}$ to more than $100 \mathrm{ft}$. Freshwater 
in the Carrizo-Wilcox aquifer is generally present in the northern two-thirds of the parish; however, saltwater is present in the aquifer under most of the Red River Valley.

Groundwater-level data from 1991 indicated water levels in the aquifer ranged from about $180 \mathrm{ft}$ above NGVD 29 along the western parish line to less than $100 \mathrm{ft}$ NGVD in the Red River Valley. Groundwater flow in the Carrizo-Wilcox aquifer is generally toward the Red River. Data from well Na-487 (fig. 4), screened in the Carrizo-Wilcox aquifer, showed decreasing water levels from 2002 to 2010 . The well is located in the western part of the parish near Robeline (fig. 1), and is $445 \mathrm{ft}$ deep.

State well-registration records listed 342 active wells screened in the Carrizo-Wilcox aquifer in Natchitoches Parish in 2010, including 267 domestic, 41 public supply, 29 irrigation, and 5 industrial wells. Depths of these wells ranged from 20 to 612 $\mathrm{ft}$ below land surface with a median well depth of $187 \mathrm{ft}$. Yields from wells screened in the aquifer in the parish range from 1 to $667 \mathrm{gal} / \mathrm{min}$. In 2005, groundwater withdrawals from the Carrizo-
Wilcox aquifer in the parish totaled about $1.23 \mathrm{Mgal} / \mathrm{d}$, primarily for public supply, irrigation, and domestic use.

A statistical summary of selected water-quality characteristics for water samples collected from 69 wells screened in freshwater areas of the Carrizo-Wilcox aquifer in Natchitoches Parish is listed in table 3. Based on median values, water from the Carrizo-Wilcox aquifer generally is soft and does not exceed the SMCLs for $\mathrm{pH}$, and chloride, iron, and manganese concentrations. Water in the Carrizo-Wilcox aquifer generally exceeds the SMCLs for color and dissolved solids concentrations.

\section{Surface-Water Resources}

In 2005, about $29.2 \mathrm{Mgal} / \mathrm{d}$ of surface water was withdrawn in Natchitoches Parish for public supply, industrial, rice irrigation, general irrigation, and aquaculture uses (table 2). Primary sources of fresh surface water in Natchitoches Parish include the Red River, Sibley Lake, Bayou Pierre, Little River, Black Lake

Table 4. Summary of selected water-quality characteristics for the Red River, Bayou Pierre, and Saline Bayou in Natchitoches Parish, Louisiana, (U.S. Geological Survey, 2012b).

[Values are in milligrams per liter, except as noted. $\mu \mathrm{S} / \mathrm{cm}$, microsiemens per centimeter at $25^{\circ} \mathrm{C} ; \mathrm{SU}$, standard units; $\mathrm{CaCO}_{3}$, calcium carbonate; $\mu \mathrm{g} / \mathrm{L}$, micrograms per liter; ND, no data; SMCL, Secondary Maximum Contaminant Level established by the U.S. Environmental Protection Agency (2011); NA, not applicable; $<$, less than; - insufficient data]

\begin{tabular}{|c|c|c|c|c|c|c|c|c|c|c|}
\hline & $\begin{array}{c}\text { Specific } \\
\text { conductance, } \\
\text { field }(\mu \mathrm{S} / \mathrm{cm} \\
\left.\text { at } 25^{\circ} \mathrm{C}\right)\end{array}$ & $\begin{array}{l}\text { Oxygen, } \\
\text { dissolved }\end{array}$ & $\begin{array}{l}\text { pH, } \\
\text { field } \\
\text { (SU) }\end{array}$ & $\begin{array}{l}\text { Hard- } \\
\text { ness (as } \\
\mathrm{CaCO}_{3} \text { ) }\end{array}$ & $\begin{array}{c}\text { Cal- } \\
\text { cium, } \\
\text { filtered } \\
\text { (as Ca) }\end{array}$ & $\begin{array}{l}\text { Mag- } \\
\text { nesium, } \\
\text { filtered } \\
\text { (as Mg) }\end{array}$ & $\begin{array}{l}\text { Sodium, } \\
\text { filtered } \\
\text { (as Na) }\end{array}$ & $\begin{array}{l}\text { Chloride, } \\
\text { filtered } \\
\text { (as CI) }\end{array}$ & $\begin{array}{l}\text { Sulfate, } \\
\text { filtered } \\
\text { (as } \mathrm{SO}_{4} \text { ) }\end{array}$ & $\begin{array}{c}\text { Iron, } \\
\text { filtered, } \\
\text { ( } \mu \mathrm{g} / \mathrm{L} \\
\text { as Fe) }\end{array}$ \\
\hline Median & 508 & 8.4 & 7.7 & 150 & 40 & 12 & 56 & 71 & 82 & ND \\
\hline 10th percentile & 242 & 6.4 & 7.3 & 67 & 20 & 4.8 & 17 & 20 & 24 & ND \\
\hline Number of samples & 67 & 62 & 68 & 66 & 66 & 66 & 67 & 67 & 67 & ND \\
\hline $\begin{array}{l}\text { Percentage of samples } \\
\text { that do not exceed } \\
\text { SMCLs }\end{array}$ & NA & NA & 100 & NA & NA & NA & NA & 97 & 97 & ND \\
\hline
\end{tabular}

\begin{tabular}{|c|c|c|c|c|c|c|c|c|c|c|}
\hline \multicolumn{11}{|c|}{ Bayou Pierre near Lake End, 1979-86² } \\
\hline Median & 495 & 7.0 & 7.2 & 160 & 39 & 16 & 34 & 38 & 38 & 30 \\
\hline 10th percentile & 223 & 4.8 & 6.5 & 57 & 15 & 5.5 & 15 & 20 & 18 & $<10$ \\
\hline Number of samples & 41 & 41 & 41 & 41 & 41 & 41 & 42 & 41 & 41 & 13 \\
\hline $\begin{array}{l}\text { Percentage of samples } \\
\text { that do not exceed } \\
\text { SMCLs }\end{array}$ & NA & NA & 93 & NA & NA & NA & NA & 100 & 100 & 100 \\
\hline
\end{tabular}

\begin{tabular}{|c|c|c|c|c|c|c|c|c|c|c|}
\hline \multicolumn{11}{|c|}{ Saline Bayou near Clarence, 1953-7833 } \\
\hline 10th percentile & 69 & 5.0 & 6.2 & 14 & 3.2 & 1.2 & 9.4 & 10 & 2.2 & - \\
\hline Number of samples & 104 & 4 & 104 & 104 & 104 & 104 & 57 & 104 & 104 & 2 \\
\hline $\begin{array}{l}\text { Percentage of samples } \\
\text { that do not exceed } \\
\text { SMCLs }\end{array}$ & NA & NA & 75 & NA & NA & NA & NA & 87 & 100 & 50 \\
\hline \multicolumn{11}{|c|}{ SMCLs } \\
\hline & NA & NA & $6.5-8.5$ & NA & NA & NA & NA & 250 & 250 & 300 \\
\hline
\end{tabular}

${ }^{1}$ Station number 07351930 (U.S.Geological Survey, 2012d; specific data at http://nwis.waterdata.usgs.gov/la/nwis/qwdata/?site_no=07351930).

${ }^{2}$ Station number 07351750 (U.S.Geological Survey, 2012e; specific data at http://nwis.waterdata.usgs.gov/la/nwis/qwdata/?site_no=07351750).

${ }^{3}$ Station number 07353000 (U.S.Geological Survey, 2012f; specific data at http://nwis.waterdata.usgs.gov/la/nwis/qwdata/?site_no=07353000). 
reservoir, and Cane River (table 1). Other major streams in the parish include Kisatchie Bayou and Saline Bayou.

About $12.9 \mathrm{Mgal} / \mathrm{d}$ of surface water were withdrawn from the Red River in 2005 (table 1). A series of 5 locks and dams, including Lock and Dam 3 near Colfax and Lock and Dam 4 near Coushatta (fig. 1), control flow on the Red River in Louisiana. The average discharge of the Red River at Alexandria, about 25 mi south of Natchitoches Parish, is about 30,900 cubic feet per second. Water samples analyzed from 1995 to 2000 indicated that water in the Red River at Grand Ecore (station number 07351930) (fig. 1) generally is hard (table 4 ) and does not exceed the SMCLs for $\mathrm{pH}$ and chloride and sulfate concentrations. Iron concentration data are not available. Dissolved oxygen is generally greater than $5 \mathrm{mg} / \mathrm{L}$, which is considered the minimum value for a diversified population of fresh, warm-water biota, including sport fish (Louisiana Department of Environmental Quality, 2008).

About $3.17 \mathrm{Mgal} / \mathrm{d}$ of water were withdrawn from Bayou Pierre in 2005 (table 1). The average discharge in Bayou Pierre near Lake End (station number 07351750) (fig. 1) was 992 cubic feet per second from October 1980 through September 2009, and the drainage area is about 860 square miles $\left(\mathrm{mi}^{2}\right)$ (U.S. Geological Survey, 2012b). Water samples analyzed from 1995 to 2000 indicated that water in Bayou Pierre near Lake End generally is hard (table 4) and does not exceed the SMCLs for $\mathrm{pH}$ and chloride, sulfate, and iron concentrations. Dissolvedoxygen concentrations generally are greater than $5 \mathrm{mg} / \mathrm{L}$.

Water samples from Saline Bayou collected from 1953 to 1978 near Clarence indicated that the water generally is soft (table 4) and does not exceed the SMCLs for $\mathrm{pH}$ and chloride and sulfate concentrations. The drainage area of Saline Bayou near Clarence (station number 07353000) is $1,386 \mathrm{mi}^{2}$.

Black Lake reservoir, located on Black Bayou, consists of two interconnected lakes: Black Lake and Clear Lake. The reservoir was completed in 1934; however, some subsequent work was done in 1949. At 100-ft elevation, the reservoir drains $920 \mathrm{mi}^{2}$, has a surface area of $20.17 \mathrm{mi}^{2}$, and has an average depth of about $8 \mathrm{ft}$. Most of Black Lake is thick with trees and other vegetation whereas Clear Lake is mostly open water. The reservoir is widely used for recreation. The water in Black Lake reservoir is generally of good quality. During the summer, however, oxygen concentrations at the bottom of the reservoir may become depleted, and hydrogen sulfide, iron, and manganese concentrations may increase to nuisance levels (Shampine, 1971).

\section{Selected References}

Hem, J.D., 1985, Study and interpretation of the chemical characteristics of natural water (3d ed): U.S. Geological Survey Water-Supply Paper 2254, $264 \mathrm{p}$.

Louisiana Department of Environmental Quality, 2008, Environmental Regulatory Code, Title 33, Part IX, Subpart 1: accessed June 9, 2009 at http:www.deq.louisiana.gov/portal/tabid/1674/Default.aspx.

Newcome, Roy, Jr., Page, L.V., and Sloss, Raymond, 1963, Water resources of Natchitoches Parish, Louisiana: Department of Conservation, Louisiana Geological Survey, and Louisiana Department of Public Works Water Resources Bulletin no. 4, 189 p.
Sargent, B.P., 2007, Water use in Louisiana, 2005: Louisiana Department of Transportation and Development Water Resources Special Report 16, 133 p.

Shampine, W.J., 1971, Chemical, biological, and physical data for the major lakes and reservoirs in Louisiana: Louisiana Department of Public Works Basin Records Report no. 5, 98 p.

Smoot, C.W., 1988, Louisiana hydrologic atlas map no. 3-altitude of the base of freshwater in Louisiana: U.S. Geological Survey Water-Resources Investigations Report 86-4314, 1 sheet, accessed November 2, 2011, at http://pubs.usgs.gov/wri/1986/4314/plate-1.pdf.

Smoot, C.W., 1989, Louisiana hydrologic atlas map no. 4geohydrologic sections of Louisiana: U.S. Geological Survey WaterResources Investigations Report 87-4288, 1 sheet, accessed February 10, 2012, at http://pubs.usgs.gov/wri/1987/4288/plate-1.pdf.

U.S. Environmental Protection Agency, 1992, Secondary Drinking Water Regulations - guidance for nuisance chemicals: U.S. Environmental Protection Agency publication EPA 810/K-92-001, 4 p., accessed September 28, 2011, at http://water.epa.gov/drink/ contaminants/secondarystandards.cfm.

U.S. Environmental Protection Agency, 2011, 2011 Edition of the drinking water standards and health advisories: U.S. Environmental Protection Agency publication EPA 820-R-11-002, Office of Water, 12 p., accessed September 2, 2011 at http://water.epa.gov/action/ advisories/drinking/upload/dwstandards2011.pdf.

U.S. Geological Survey, 2012a, Groundwater levels for Louisiana: National Water Information System Web Interface accessed November 18, 2011, at http://nwis.waterdata.usgs.gov/la/nwis/ gwlevels.

U.S. Geological Survey, 2012b, Water quality samples for Louisiana: National Water Information System Web Interface, accessed March 18, 2008, at http://nwis.waterdata.usgs.gov/la/nwis/qwdata/.

This fact sheet was published by the U.S. Geological Survey, in cooperation with the Louisiana Department of Transportation and Development (DOTD). Thanks are given to Zahir "Bo" Bolourchi, Director, Water Resources Programs, Louisiana Department of Transportation and Development, who contributed to the content and design of the fact sheet.

\section{By Robert B. Fendick, Jr., Lawrence B. Prakken, and Jason M. Griffith}

\section{For additional information, contact:}

Director, USGS Louisiana Water Science Center

3535 S. Sherwood Forest Blvd., Suite 120

Baton Rouge, LA 70816

E-mail: dc_la@usgs.gov

Fax: (225) 298-5490

Telephone: (225) 298-5481

Home Page: http://la.water.usgs.gov 